\title{
Turtles, indians and settlers: Podocnemis expansa exploitation and the Portuguese settlement in eighteenth-century Amazonia
}

\author{
Christian Fausto Moraes dos Santos ${ }^{1^{*}}$ \\ ${ }^{1}$ Universidade Estadual de Maringá, Maringá/PR - Brasil \\ Marlon Marcel Fiori ${ }^{2^{* *}}$ \\ ${ }^{2}$ Universidade Estadual de Maringá, Maringá/PR - Brasil
}

\begin{abstract}
During the eighteenth century, Portuguese settlers in Amazonia captured thousands of turtles and crushed millions of their eggs. These turtles, especially the Giant South American River Turtle (Podocnemis expansa), gave these settlers two essential resources: meat and oil. Though there is a rich historiography on turtle hunting, important social and environmental dimensions of the practice in Amazonia during the colonial period have been overlooked. In this paper we focus on how turtles played a key role in the diet and domestic needs of Portuguese settlers in the Amazon rainforest and explore the shape and magnitude of colonialism's impact on these animals. The turtles became prime targets for Portuguese settlers because they were abundant and had characteristics and behavior that made them easy prey. Though $P$. expansa did not become extinct, Portuguese hunting had enduring impacts on their distribution and abundance that merit consideration.
\end{abstract}

Keywords: Amazon; Giant South American River Turtle; Portuguese settlers; Eighteenth century.

DOI: http://dx.doi.org/10.1590/2237-101X02104404

Artigo recebido em $1^{\circ}$ de março de 2019 e aceito para publicaçáo em 26 de setembro de 2019.

* Professor da Universidade Estadual de Maringá / Departamento de História, Maringá/PR - Brasil. E-mail: chrfausto@gmail.com. ORCID: https://orcid.org/0000-0002-7537-4547.

** Doutor em História pela Universidade Estadual de Maringá / Laboratório de História, Ciências e Ambiente / UEM, Maringá/PR - Brasil. E-mail: marlonfiori@gmail.com. ORCID: https://orcid.org/0000-00016507-0788. 


\section{Tartarugas, índios e colonizadores: a exploraçáo de Podocnemis expansa e o povoamento português na Amazônia setecentista}

\section{RESUMO}

Milhares de tartarugas foram capturadas e milhóes de seus ovos foram esmagados na Amazônia setecentista. As tartarugas, sobretudo as tartarugas-da-Amazônia (Podocnemis expansa), forneceram aos colonizadores portugueses dois recursos essenciais: carne e óleo. Apesar da longa história de caça a esses animais, importantes dimensóes sociais e ambientais da história colonial amazônica têm sido pouco abordadas. $\mathrm{O}$ artigo analisa como as tartarugas desempenharam um papel fundamental na dieta e nas necessidades domésticas dos colonos portugueses nesse ambiente e explora a forma e a magnitude do impacto colonial sobre tais animais. A profusão de tartarugas encontradas nas praias, suas características e comportamento, notadamente aquelas apresentadas pela tartaruga-da-amazônia, fizeram com que essa espécie se tornasse o principal alvo dos colonizadores. $P$. expansa não foi extinta. Contudo, a distribuição e abundância das populaçôes de tartarugas-da-Amazônia ao longo do tempo, bem como o impacto da exploração portuguesa sobre tais animais devem ser considerados.

Palavras-chave: Amazônia; tartaruga-da-Amazônia; colonizadores portugueses; século XVIII.

\section{Tortugas, indios y colonizadores: la explotación de Podocnemis expansa y el poblamiento portugués en el Amazonas del siglo XVIII}

\section{RESUMEN}

Miles de tortugas fueron capturadas y millones de sus huevos fueron aplastados en el Amazonas del siglo XVIII. Las tortugas, sobre todo las tortugas del Amazonas (Podocnemis expansa), proporcionaron a los colonizadores portugueses dos recursos esenciales: carne y aceite. A pesar de la larga historia de caza de estos animales, importantes dimensiones sociales y ambientales de la historia colonial del Amazonas ha sido poco tratada. El artículo analiza cómo las tortugas desempeńaron un papel fundamental en la dieta y las necesidades domésticas de los colonos portugueses en este ambiente y también explora la forma y la magnitud del impacto colonial sobre estos animales. La abundancia de tortugas encontradas en las playas, sus características y comportamiento, notoriamente aquellas presentadas por la tortuga del Amazonas, hicieron con que esta especie se convirtiese en el principal blanco de los colonizadores. Podocnemis expansa no fue extinguida, con todo, la distribución y abundancia de las poblaciones de las tortugas del Amazonas, a lo largo del tiempo y bien con el impacto de la explotación portuguesa sobre estos animales deben ser considerados. 
Palabras clave: Amazonas; tortugas del Amazonas; colonizadores portugueses; siglo XVIII.

\section{Introduction}

In recent decades, the number of works dealing with the multiple historical interactions between humans and animals after the arrival of Europeans in the New World has grown exponentially. Scholars have pointed out that all sorts of animals, as well as animal parts, historically played an influential role in the colonial Americas, as nonhuman actors, with strong economic, cultural, social and scientific implications. Bringing the animal into their analysis, scholars have expanded our understanding on their remarkable impact in colonial economy and society, in religion and biblical narrative, medicinal practices, and scientific ideas. In other words, scholars showed how important animals were to different aspects of New World colonial history ${ }^{1}$. The theme of this essay converses with a recent and significant body of historical work dealing with animals in colonial Americas, especially scholarship about how exploitative practices of settlers have wreaked havoc on some particular species of New World fauna.

Portuguese permanent settlement in Amazon started in the early seventeenth century. The city of Belem was founded in 1616, when the Dutch and English established trading posts in the estuary of the Amazon River. The Portuguese gradually expelled other European settlers and from the 1640s onwards they acquired considerable dominion over the region. Until at least the late 1780s or early 1790s, the Amazonian economy revolved around Indian labor and the extraction of a variety of wild products (locally called drogas do sertão), like cacao, clove-bark and salsaparrilla. At the same time, the Portuguese crown encouraged the cultivation of profitable native spices, sugar, and tobacco (CHAMBOULEYRON, 2006; CHAMBOULEYRON, 2014; ROLLER, 2013). Settlers brought with them domestic animals and European crops, but many exotic plants and animals did not adapt well. Introduced species were plagued by a host of unwelcome insects, parasites and fungi, and had to adapt to rainforest environmental conditions, such as intense heat and high annual precipitation. In the second half of the eighteenth century, Alexandre Rodrigues Ferreira commented that in the rainforest cultivated cabbages rotted, kale became woody and unpalatable, and mangoes fell off the tree prematurely, when they were as small as a musket ball. He lamented that the Rio Negro's livestock numbered less than 400 heads of cattle, although there was good pasture for many more (FERREIRA, 1983, p. 383-385, 687).

\footnotetext{
${ }^{1}$ See, for example, FEW; TORTORICI, 2013; ASÚA; FRENCH, 2005; ANDERSON, 2006. There is also a recent literature on turtle hunting and conservation, see, for exemple, HENNESSY, 2014; CRAWFORD, 2017.
} 
In the Amazon rainforest, the Portuguese settlers forged livelihoods from the rich riverine ecosystems that were home to abundant fishes, manatees and chelonians. Eighteenthcentury accounts often refer to the hunting and fishing of these animals. Turtles, primarily the giant South American river turtle, were particularly attractive targets. The females were hunted on Amazonian rivers' beaches during nesting periods, and a large number of their eggs were used in the production of an oil, known as turtle-egg butter (manteiga dos ovos), which was used by the Portuguese for cooking, caulking of vessels, and was especially useful as an abundant fuel to light houses and streets.

The long history of turtle hunting notwithstanding, scholars tends to pay little attention to the Amazon colonial period. There is, of course, important works which examine turtle exploitation. However, the colonial period has rarely been the primary focus of such scholarship. Instead, biologists, geographers, anthropologists and historians mainly addressed the nineteenth century ${ }^{2}$. As David Cleary pointed out the "colonial extractivist boom has long been overshadowed by the more famous boom of the nineteenth and early twentieth centuries, but its environmental consequences were just as dramatic" (CLEARY, 2001, p. 84) $)^{3}$.

In this paper we focus on how turtles played a key role in the diet and domestic needs of the Portuguese settlers in Amazon rainforest and explore the shape and magnitude of colonial impacts on these animals during the eighteenth century. For Portuguese settlers, turtles were an essential source of meat, as well as oil. Our objective is to highlight the historicity of the relationships between colonizers and turtles. In doing so, our approach pays close attention to turtle ecology and life processes informed by contemporary biology. This paper helps us understand the importance of turtles in the Amazonian colonial context and explores the ecological significance of colonization for its animals.

\section{Giant South American River Turtle and other chelonians}

In 1783, Alexandre Rodrigues Ferreira arrived in Amazonia to enumerate the potential agricultural and other natural resources available for exploitation in this region of Portuguese America. He was accompanied by two sketch artists, José Joaquim Freire and Joaquim José Codina, and a botanical gardener ${ }^{4}$. The natural philosopher spent nearly a decade in Amazonia and during his journey he produced a series of detailed reports on plants,

\footnotetext{
${ }^{2}$ See VERÍSSIMO, 1970; SMITH, 1974; SMITH, 1979; MITTERMEIER, 1975; KLEMENS; THORBJARNARSON, 1995; ANDERSON, 1999, p. 52-57; GILMORE, 1987, p. 216-220; VOGT, 2004; VOGT, 2008, p. 14-16; COSTA, 2012.

${ }^{3}$ For a more systematic and comprehensive study see MACHADO, 2016.

${ }^{4}$ On Ferreira see GOELDI, 1982; RAMINELLI, 1998; PATACA, 2011; MORAES; SANTOS; CAMPOS, 2011.
} 
minerals and animals, including three short reports on the turtles. Ferreira's interest and close attention to turtles offers eloquent testimony of the importance of these animals in the livelihood of Portuguese settlers. According to him, turtles were "[...] an incredibly useful animal: the everyday beef of Portuguese and Indians' tables in every village" (FERREIRA, 1903, p. 181). Why were turtles such an attractive resource for the Portuguese in the Amazon rainforest?

The Brazilian Amazon is home to 14 freshwater turtle species (VOGT; MOREIRA; DUARTE, 2001, p. 89-90). Many native species were used as food by Portuguese settlers. However, the giant South American river turtles (Podocnemis expansa) were the primary quarry. Generally speaking, Amazonian chelonians vary in body size, behavior, ecology, diet and distribution', but the giant South American river turtles have many physical, behavioral and ecological characteristics which made them such an attractive target for hunters. First, they are big creatures. The giant South American river turtle is the biggest freshwater chelonian in South America. Mature animals range from 25 to 45 kilograms and an adult yields up to seven kilograms of meat. The females, more vulnerable to hunting, are somewhat bigger than males; the biggest ever-registered female weighed impressive 90 kilograms (VOGT, 2004, p. 87). Ferreira reported that each giant South American river turtle supplied enough meat for ten or more soldiers (FERREIRA, 1972, p. 27-28). Second, the giant South American river turtle were easy to locate. The species has a wide distribution in Amazonian rivers, and can be found in black water, white water and clear water rivers. Many Amazonian freshwater turtles have far more restricted distributions (VOGT; MOREIRA; DUARTE, 2001, p. 90-91; VOGT, 2004, p. 237). Third, they were particularly vulnerable.

The giant South American river turtle has a nesting behavior similar to that of some marine turtles. Females climb up the river sandbanks (locally denominated beaches or tabuleiros) in large groups ou arribadas. This behavior is unlike that of any of Amazonian freshwater turtles, which nest in small groups or alone. . The group nesting behavior of $P$. expansa is related to an increase in hatchling survivorship and a decrease in the chances that females are captured by predators (FERRARA et al., 2014, p. 149-150; BEST, 1984, p. 390). However, giant South American river turtles group nesting behavior made them vulnerable and particularly attractive prey to human hunters.

Giant South American river turtle nesting beaches usually host other species' nests, such as the yellow-spotted Amazon river turtle (Podocnemis uniflis) and the six-tubercled Amazon River turtle (Podocnemis sextuberculata), but the number of their nests in the same beach is considerably smaller, generally less than 10 percent (CANTARELLI; MALVASIO; VERDADE, 2014, p. 127). During hunting excursions, females of these and other turtle species that were potential sources of food were occasionally collected on nesting beaches.

${ }^{5}$ See VOGT, 2008. 
Nevertheless, some turtles were avoided or hardly eaten by Portuguese settlers. Matamata turtle (Chelus fimbriatus), with its elongated snout and wart-like protuberances around its neck, was not eaten (FERREIRA, 1972, p. 29), possibly due to its strange appearance and strong musky odor (FACHÍN-TERÁN; VOGT; THORBJARNARSON, 2004, p. 373). Big-headed sideneck turtle (Peltocephalus dumerilianus), for reasons that are still unclear, was considered an inferior turtle and was eaten only by Indians and lower classes (FERREIRA, 1972, p. 28).

Fourth, giant South American river turtles were abundant. Eighteenth century reports repeatedly described the prodigious numbers of $P$. expansa females during nesting period. Between 1753 and 1761, Giovanni Angelo Brunelli ${ }^{6}$ travelled across Amazonia as an astronomer of the first boundary expedition ${ }^{7}$ to Spanish and Portuguese America. In 1791, he published De Flumine Amazonum [About the Amazon River]. In this work, the Italian astronomer commented how a large number of giant South American river turtles covered leagues on the beaches:

When, in these months [of dry season], the little water from all these rivers, run in small depth, this way, get so further from the margins that the accumulated sand appear in big amounts, almost all female turtles leaving the waters from all sides search these areas to lay their eggs. So, great stretches of land become darkened in an admirable way, that stands for many leagues (BRUNELLI, 2011, p. 149).

In 1774, the crown of judge Francisco Xavier Ribeiro de Sampaio ${ }^{8}$ noticed that during nesting period in the Solimôes River "[...] the turtles go out to nest in such huge numbers that they fill the beach, and yet many stay on the riverbank, waiting for the other turtles to finish, so they could nest" (SAMPAIO, 1825, p. 122). Almost thirty years earlier, French explorer and geographer Charles-Marie de la Condamine described how the turtles were so abundant in Amazonian rivers that "[...] they and their eggs could be sufficient to feed the residents of their margins" (CONDAMINE, 1745, p. 158).

Finally, giant South American river turtles were important as a source of eggs. During the nesting season, giant South American river turtles' arribadas, with large aggregations of females emerging to nest and a large numbers of eggs per clutch, provided substantial opportunities for massive collection of eggs. Usually, the giant South American river turtle nests at night and its reproductive process slow. Digging a hole in the sandy beache and laying eggs and burying them takes a couple of hours. The eggs are round and have a flexible shell. The number of eggs per nest depends on the size of the female specimen. A clutch

\footnotetext{
${ }^{6}$ On Brunelli see PAPAVERO et al., 2010.

${ }^{7}$ For a brief account of the Amazonian boundary expeditions see DOMINGUES, 1991; RAMINELLI, 2008, p. 69-74.

${ }^{8}$ On Sampaio see SAFIER, 2007.
} 
usually has on average 95 to 100 eggs, but bigger females can lay up to 180 eggs (VOGT, 2008, p. 10-14; MITTERMEIER, 1975, p. 9; GOUDING, 1997, p. 159). During the egglaying season, huge piles of eggs were easily accumulated by digging up the giant South American river turtles' nests. They were mainly converted to oil, called manteiga dos ovos (turtle eggs butter).

The settlers used turtle egg oil for caulking vessels, cooking, and lighting villages and homes. Turtle oil was abundant enough to meet Portuguese demands for calories and fuel, counterbalancing the local scarcity and high prices of imported olive oil or butter. Contemporaries fully recognized the importance of turtle-egg butter. As the Italian architect Antonio Giuseppe Landi" wrote in the 1760s, the egg butter was "[...] the redemption of this land, considering it can be used for cooking as well as lighting [...]” (LANDI, 2002, p. 178-179). A German Jesuit observer also reported that the egg butter was "[...] the ordinary butter in these cities, and also in the communities and villages [...]", because "[...] the butter from Portugal is too expensive" (ECKART, quoted from PAPAVERO et al., 2011, p. 600). The demand for oil was also supplied by the blubber of Caribbean manatee and the Amazonian manatee (DOMNING, 1982, p. 102-03; FIORI; SANTOS, 2015, p. 75-92).

The profusion of turtles found in the beaches, the turtles' characteristics and behavior, especially those of the giant South American river turtle, offered an opportunity for settlers obtain eggs and a valuable stock of meat without serious obstacles and the number of females captured and eggs harvested along riverbanks was high.

\section{The eighteenth-century turtle hunting}

Turtles were captured year-round, using bow and arrow, and hooks baited with fruits and nets to catch them in the rivers and lakes (FERREIRA, 1972, p. 33-34). The dry season was an ideal opportunity to collect females while they were laying eggs on nesting beaches, because just overturning them prevented escape. "When the turtles are on the beaches is when provision makes the most because we catch them with bare hands, and turn them with their backs to the ground, making impossible for them to turn back, and we carry them to the boats", wrote Francisco Xavier Ribeiro de Sampaio, around 1770 (SAMPAIO, 1825, p. 86).

In the turtle nesting season, especially from October to December, groups of Portuguese settlers and Indians plunged into the riverbanks of the Amazon and its tributaries and loaded their canoes with females and egg butter (FONSECA, 1826, p. 17; FERREIRA, 1903, p. 182). In addition to residents' flotillas, colonial officials of every village or community recruited Indians and sent out a canoe for eggbutter production, probably to supply the oil

\footnotetext{
${ }_{9}^{9}$ On Landi see MEIRA FILHO, 1976.
} 
used for public lighting (FERREIRA, 1972, p. 34-35; FERREIRA, 1972, p. 27). During the turtle harvest, thousands of females were captured. According to the Jesuit priest Antônio Moreira's report, there were "occasions that a single native turns 200 or more [...]" turtles (MOREIRA, quoted from PAPAVERO; TEIXEIRA, 2011, p. 122). Ferreira reported that hunters usually captured 50 to 100 turtles quickly and with little effort (FERREIRA, 1972, p. 27). Turtles were collected and killed in such high numbers that at times their carcasses nwere used for curious purposes. As Ferreira described, in Barcelos village, located along the Negro River, shells served as pathways along the muddy streets (FERREIRA, 1903, p. 186).

Hunters waited for females to lay their eggs before turning them (FERREIRA, 1972, p. 27). Giant South American River turtle's carapace is flat and females are unable to right themselves. When caught, turtles provided an abundant and much-needed source of fresh meat in an environment where freshly killed animals spoiled quickly. The temperature remains high throughout the year in Amazon rainforest. The average annual temperatures are often above $26^{\circ} \mathrm{C}$ and the daily temperature ranges are usually far greater than the annual range. The relative humidity is equally high: $76 \%$ in September, during the dry season, and 87\% during the wet season (IRION; JUNK; MELLO, 1997, p. 30). This hot and wet environment maximizes the fungal and bacterial activity. The scarcity of salt ${ }^{10}$, and the presence of flies and other insects were additional problems for meat preservation. João Daniel, a Jesuit priest who lived in the Amazon between 1741 and $1757^{11}$, complained that the New World screw-worm fly (Cochliomyia hominivorax), locally known as varejeiras or varejas, were "the biggest enemy of meats and dried fishes, when they are put under the sun, soon come the varejas, and from them originates the vermin, and from these the corruption and putridity [...] and in the Amazon they are plague, and plague of all time" (DANIEL, 1976, p. 165).

Due to the problems of storing meat and fish, turtles were not killed immediately after being caught. Usually they were penned in fenced lagoons or pools, commonly known as curral (FERREIRA, 1903, p. 184). Since the giant South American river turtle has the ability to survive months with little or no food, turtles could be kept for long periods in these pens, where they were slaughtered as needed. Thus turtles helped to some extent to mitigate the lack of fresh meat during the months of rising water. When the rivers rise, an expanded area becomes available for fish, turtles and other aquatic animals, so catches tend to be higher only when the water recedes (GOUDING, 1997, p. 157).

Indians kept turtles in pens prior to European settlement in the Amazon, as suggested by the account of Friar Gaspar de Carjaval, who went down the Amazon River in 1542 with Spanish explorer Francisco de Orellana; turtle pens were also recorded by Priest Cristóbal de Acuña almost one century later (CARVAJAL, 1992, p. 56; ACUÑA, 1641, p. 11). Over the

\footnotetext{
${ }^{10}$ For an overview see HOLANDA, 2000, p. 51, 91-92.

${ }^{11}$ On Daniel life and works see COSTA, 2007.
} 
past few decades, many scholars have stated that indigenous people lived in fairly large-scale societies across Amazonia. There were dense population settlements along the major rivers, combining farming systems with fishing. Turtles provided a substantial protein supply for Indian societies. During the nesting season, Indians harvested turtle females for meat and collected eggs for nutritional purposes and probably to make oil ${ }^{12}$.

Indians and Portuguese settlers also tracked nesting beaches looking for eggs. They found nests by piercing the sand with arrows or any pointed object (DANIEL, 1976, p. 95), or by simply stomping their feet on the ground. The astronomer Brunelli described, in astonishment, the hunters' expertise at finding turtle eggs:

By stomping their feet, [...] the inhabitants usually discover where the eggs are. In this way, they accumulate an almost incredible number of eggs, from which, as the Portuguese say, is extracted the butter. Almost all Brazilian nations serve from it for cooking. It's also used as fuel for lamps (BRUNELLI, 2011, p. 149-151).

The turtle egg butter used for cooking and lighting was prepared by filling canoes with thousands of eggs and stomping on them. Water was then poured on it and this mixture was left exposed to the sun until heat brought the oil to the surface. Lastly, the oil was skimmed off, boiled and stored in clay pots locally known as camotins. The eggs were sometimes left in the sun for four to five days to obtain denser oil, but this oil, rancid and fetid as described by Ferreira, was only used as fuel and as caulking for vessels (FERREIRA, 1972, p. 27; FERREIRA, 1972, p. 34-35). When hatchlings were found, they were roasted and eaten by those involved in the egg oil production (FERREIRA, 1903, p. 184).

The sketch artists who accompanied Ferreira's expedition to the Amazon depicted the turtle egg harvest and egg oil production. The drawing represented in visual form all the process involved in egg butter production (Figure 1). To the left (1 and 3), Indians are searching for and collecting turtles' eggs. The image draws attention to the Indians' ability to find turtle nests using piercing objects. At the top (2), there are turtles caught and penned. At the center (4), Indians are stomping thousands of eggs into a canoe. To the right (5 and 7 ), the egg mixture is boiled for purification and reduction, and stored in clay pots. Here the image depicts a man wearing a hat, probably a settler in charge of egg oil purification and production, as well as an Indian roasting some hatchlings (6). Ferreira criticized the capture of hatchlings for food and the waste incurred in egg butter production, which he attributed to Indians (FERREIRA, 1903, p. 184). Behind all steps of egg oil production that the drawing depicts lay Indian labor, which affirms the importance of Indian work in the eighteenth-century turtle exploitation.

\footnotetext{
${ }^{12}$ See, for example, CLEMENT et al., 2015; GILMORE, 1987, p. 654-81; CRAMPTON; CASTELLO; VIANA, 2004, p. 79; DENEVAN, 1996.
} 


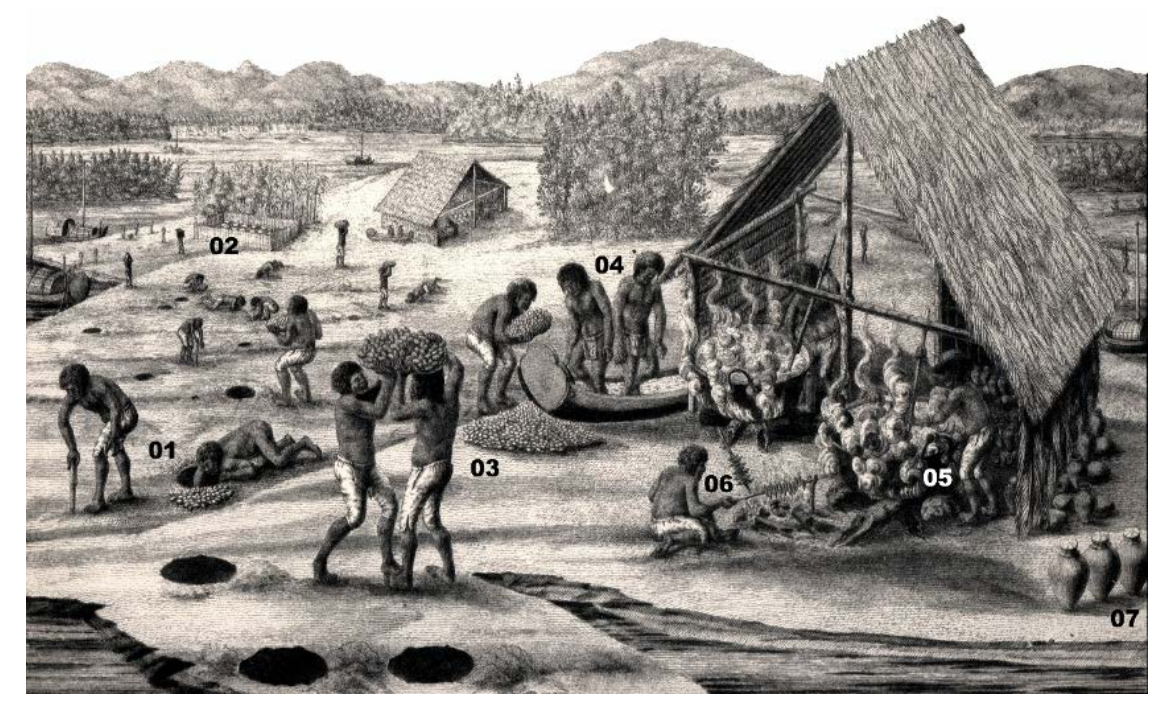

Figure 1 - Source: Fabrico da manteiga dos ovos da tartaruga [Production of turtle eggs butter]. Viagem Philosophica (1783-1792). Rio de Janeiro, Biblioteca Nacional, Coleção Alexandre Rodrigues Ferreira.

How many eggs were used to produce one pot of turtle egg butter? Eighteenth century sourcesdo not say, but some sources provide enough information to support an estimate. In addition, it is possible that the size of clay pots has changed over the centuries. The long history of turtle egg butter exploitation notwithstanding, scholars tends to focus on Henry Walter Bates' nineteenth century report. Both Bates and the naturalist Alfred Russell Wallace traveled to Amazonia in 1848, to collect animals and to compile observations in natural history. Bates arrived home in 1859 after a full eleven years in the tropical forest and would later publish a travel journal.

In 1850, Bates arrived in Ega, a village situated along the Tefé River, a tributary of the Solimóes River, where he became involved in expeditions with local inhabitants to collect specimens. During these expeditions, Bates had the opportunity to see the egg harvest and the production of turtle egg butter (BATES, 1864, p. 331-345). The naturalist estimated that every year the local inhabitants produced around 8,000 jars of turtle egg oil in the higher portion of the Amazon River and in Madeira River. Since each pot consumed 6,000 eggs, local residents crushed 48,000,000 eggs to supply the demand. Considering an average of 120 eggs per clutch, this required the nests of 400,000 turtle females:

At least 6000 jars, holding each three gallons of the oil, are exported annually from the Upper Amazons and the Madeira to Pará, where it is used for lighting, frying fish, and other purposes. It may be fairly estimated that 2000 more jars-full are consumed by the inhabitants of the villages on the river. Now, it takes at least twelve basketfull of eggs, or about 6000, by the wasteful process followed, to make one jar of oil. The total number of eggs annually destroyed 
amounts, thefore, to $48,000,000$. As each turtle lays about 120 , it follows that the yearly offspring of 400,000 turtles is thus annihilated (BATES, 1864, p. 364-365).

There is no reason to contest the number of eggs suggested by Bates. However, eighteenth century reports suggest a smaller number of eggs was needed to produce one pot of turtle egg butter. The Jesuit missionary Antônio Moreira suggested that at least 1,500 eggs were used (MOREIRA, quoted from PAPAVERO; TEIXEIRA, 2011, p. 122). Another Jesuit wrote that at least 1,000 eggs needed to be collected (DANIEL, 1976, p. 294). The natural philosopher Alexandre Rodrigues Ferreira reported that the hunters dig up eleven clutches to obtain each pot of oil (FERREIRA, 1903, p. 183); that is, around 1,050 to 1,100 eggs, insofar as females typically lay 95 to 100 eggs per clutch (VOGT, 2008, p. 10-14; MITTERMEIER, 1975, p. 9; GOUDING, 1997, p. 159). Although these accounts are not precise about the number of eggs, they offer a glimpse into the size of the egg harvest to supply the demand for oil.

In the egg-laying season, the architect Landi reported that each canoe usually produced up to 800 pots of oil (LANDI, 2002, p. 178-179). Ferreira described that a skilled crew normally loaded their canoe with 1,000 pots, although the number of pots decreased when the nests were flooded by unseasonal rising river levels. On the other hand, he pointed out that when the hunters obtained a more profitable egg harvest, a skilled crew was able to produce 2,000 pots of oil (FERREIRA, 1903, p. 183). If we assume that, on average, 1,300 eggs were used to produce one pot of butter, the number of eggs excavated to load a single boat usually would have ranged between $1,040,000$ to $1,300,000$ eggs or the clutches from 10,000 to 13,000 females. In the major egg harvest beaches, where the canoes flotillas concentrated its activities, several millions of eggs were excavated. The major egg harvest beaches included the Saracá Lake area. An account reported that year after year, flotillas landed on the shores of the lake and produced several thousand pots of turtle egg butter (DANIEL, 1976, p. 36). The crown of judge Sampaio also noticed that in the Solimóes River, near the mouth of the Purus River, were produced "annually several thousands of turtle eggs butter" (SAMPAIO, 1825, p. 19). Turtle nesting beaches in Madeira and Tapajós River were other profitable areas (MOREIRA, quoted from PAPAVERO; TEIXEIRA, 2011, p. 121-22; ECKART, quoted from PAPAVERO et al., 2011, p. 600).

According to the Priest Cypriano Pereira Alho, vicar of the church of Moreira at the beginning of $1790 s^{13}$, a village on the São José do Rio Negro Captaincy, the total amount of turtle eggs butter produced in a single year could reach 100,000 pots. In 1819, he edited the first print edition of the heroic poem, The Muhraida, or the conversion and reconciliation of the Heathen Mura, written in 1785 by Henrique João Wilkens, a military and engineer who spent almost 50 years in the Amazon (TREECE, 2000, p. 68; PAPAVERO; TEIXEIRA,

${ }^{13}$ On Pereira Alho see PAPAVERO; TEIXEIRA, 2000. 
2000, p. 1-5). In his edition, Alho appended the Wilken's poem with footnotes and commented on the extraordinary turtle egg oil production:

[...] such has been the abundance [of turtle egg oil production], that there were years in VillaNova da Rainha (Thupynambá-râna), where the producers in this business paid the tithe, there were years of 10 to 12,000 pots [paid]; incredible number that if I had not seen them in reports that were sent to the Secretary, I would never believe [...] (ALHO, 1819, p. 188).

Assuming that Alho's description is reasonably accurate, the annual turtle egg butter production reached from 100,000 to 120,000 pots, considering that colonial administration imposed a 10 percent tax and in Vila Nova da Rainha, where the tax was collected, the total number of pots paid amounted to 10,000 to 12,000 . So, in a single year, the hunters might harvest $130,000,000$ to $160,000,000$ eggs or the clutches of more than 1,000,000 females, what required around one hundred canoes, due to the average production per canoe.

Turtle meat also was the main source of protein for soldiers and boundary expeditions. Indians collected giant South American river turtles during the egg-laying season and a large number of females were kept in captivity. In 1754, more than 3,000 turtles were collected in the Saracá Lake region to supply the first boundary expedition, led by Francisco Xavier de Mendonça Furtado ${ }^{14}$, the general-governor of Grão-Pará and Maranhão State. In the next year, between January and July, more than 1,698 turtles were sent to the expedition headquarter, the Mariuá aldeia, on the Negro river ${ }^{15}$.

In the 1780s, the number of turtles collected to feed the second boundary expedition was even higher. Between 1780 and 1788, more than 36,000 turtles were sent to pens in Barcelos, previously Mariuá aldeia. These animals were captured mainly in two pesqueiros reais (Royal Fisheries), Poraquecoara and Rio Branco, fishing grounds established by the colonial administration to produce valuable catches of turtles, fishes and manatees (Table 1):

\footnotetext{
${ }^{14}$ Mendonça Furtado ruled the State of Grão-Pará and Maranhão between 1751 and 1759. On Furtado, see RAYMUNDO, 2006.

${ }^{15}$ Ofício do [governador do Estado - Pará e Maranhão], Francisco [Xavier de Mendonça Furtado] ao [secretário de Estado dos Negócios do Reino], Sebastião José de Carvalho e Melo sobre provisão de mantimentos, Arraial de Mariuá, 13 Jul. 1755, Arquivo Histórico Ultramarino (hereafter cited as AHU)_CU_020, Cx. 1, D. 34 .
} 
Table 1: Turtles sent from Poraquecoara and Rio Branco Royal fishing posts to the captivity of Barcelos village (1780 to 1788$)$

\begin{tabular}{|c|c|}
\hline Year & Turtles \\
\hline $1780(\mathrm{a})$ & 1,471 \\
\hline $1781(\mathrm{~b})$ & 5,116 \\
\hline $1782(\mathrm{c})$ & 4,763 \\
\hline $1783(\mathrm{~d})$ & 4,557 \\
\hline $1784(\mathrm{e})$ & 4,518 \\
\hline $1785(\mathrm{f})$ & 4,410 \\
\hline $1786(\mathrm{~g})$ & 4,264 \\
\hline $1787(\mathrm{~h})$ & 3,474 \\
\hline $1788(\mathrm{i})$ & 3,826 \\
\hline Total & 36,399 \\
\hline
\end{tabular}

Sources: (a) Ofício do [encarregado das demarcaçôes do Rio Negro e capitão-general], João Pereira Caldas, ao [secretário de Estado da Marinha e Ultramar], Martinho de Melo e Castro, sobre a prestação de contas dos gastos da expedição no ano de 1780, Vila de Barcelos, 22 jul. 1781, AHU_CU_020, Cx. 4, D. 221; (b) Ofício do [encarregado das demarcaçóes do Rio Negro e capitão-general], João Pereira Caldas, a [secretário de Estado da Marinha e Ultramar], Martinho de Melo e Castro, a enviar as relaçóes das despesas feitas em 1781 pela Junta da Real Fazenda do Pará com a expedição das demarcaçóes do Rio Negro, Vila de Barcelos, 5 feb. 1783, AHU_CU_020, Cx. 6, D. 264; (c) Ofício do [encarregado das demarcaçóes do Rio Negro e capitão-general], João Pereira Caldas, ao [secretário de estado da Marinha e Ultramar], Martinho de Melo e Castro, sobre as despesas da Repartição das Demarcaçóes no ano de 1782, Vila de Barcelos, 20 Oct. 1783, AHU_CU_020, Cx. 7, D. 297; (d) Ofício do [encarregado das demarcações do Rio Negro e capitão-general], João Pereira Caldas, ao [secretário de Estado da Marinha e Ultramar], Martinho de Melo e Castro, a enviar as contas da Repartição das Demarcaçóes, relativas aso ano de 1783, Vila de Barcelos, 20 Feb. 1785, AHU_ CU_020, Cx. 9, D. 371; (e) FERREIRA, 1903, p. 186; (f) FERREIRA, 1903, p. 186; (g) Ofício do [capitãogeneral], João Pereira Caldas, ao [secretário de Estado da Marinha e Ultramar], Martinho de Melo e Castro, sobre as despesas relativas ao ano de 1786, feitas pela Repartição das Demarcaçóes de Limites, a bordo da canoa Nossa Senhora do Pilar, 15 Jun. 1789, AHU_CU_020, Cx. 15, D. 564; (h) Ofício do [capitão-general], João Pereira Caldas, ao [secretário de estado da Marinha e Ultramar], Martinho de Melo e Castro, sobre as despesas relativas ao ano de 1787, feitas pela Repartiçáo das Demarcaçôes de Limites, a bordo da canoa Nossa Senhora do Pilar, 15 Jun. 1789, AHU_CU_020, Cx. 15, D. 566. 
Ferreira also registered that the number of turtles harvested in the other state fishing ground, the pesqueiro da Capitania, between 1780 and 1785, surpassed 16,000 (Table 2):

\begin{tabular}{|c|c|c|}
\hline Year & Entries & Deaths \\
\hline 1780 & 2,740 & 765 \\
\hline 1781 & 2,846 & 876 \\
\hline 1782 & 2,728 & 770 \\
\hline 1783 & 2,892 & 833 \\
\hline 1784 & 2,710 & 1,217 \\
\hline 1785 & 2,896 & 1,600 \\
\hline Total & 16,816 & 6,061 \\
\hline
\end{tabular}

Source: FERREIRA, 1903, p. 185.

In addition to shedding light on the large number of turtles harvested, historical sources may also help us to understand the wastefulness in royal fisheries. Ferreira registered that 11,400 animals died in the pens of Barcelos Village between 1780 and $1785^{16}$. Over the same period, the combined number of turtles wasted in Barcelos and in pesqueiro da Capitania was more than 17,000 , for a total of 41,647 , or 41.9 percent. Overcrowding, starvation, and exhaustion all probably accounted for the high number of deaths. Many turtles also died from injury or stress prior to arriving in the royal fisheries and these animals were not recorded in the state reports. The natural philosopher pointed out that these reports did not include the turtles which "[...] died in transport canoes during the journey from the fishing grounds to the village, these numbers are more or less, depending the hot or warm season, the amount of cargo in the canoes, and the turtles' condition, such as if they had nested or not" (FERREIRA, 1903, p. 186).

Some settlers viewed the turtle abundance as a prodigious or as a limitless resource. In 1749, an official wrote that if the Portuguese did not kill such large numbers of these animals, the Amazon River and its tributaries "[...] would be somewhat difficult to navigate, due to the difficulty caused by the strangest abundance [of turtles] that one could only

\footnotetext{
${ }^{16}$ A careful examination of second boundary expedition's historical records shows that Ferreira's analysis has a gap (See FERREIRA, 1903, p. 185). Therefore, our data may be in disagreement to other studies that used exclusively Ferreira's records as a source, such as SMITH, 1974, p. 94.
} 
imagine" (FONSECA, 1826, p. 17). The bishop João de São Joseph Queiroz commented that the rivers "would run chock-full of turtles" if there were no egg harvest for the oil production (QUEIROZ, 1869, p. 76).

On the other hand, some reports commented on how turtles suffered population declines after Portuguese settlement in Amazonia. As the Jesuit priest Antônio Moreira observed, turtles were still "innumerable" despite predation by many natural enemies and human hunters. However, he argued that "the Indians told me that in the old days there were much more [turtles]" (MOREIRA, quoted from PAPAVERO; TEIXEIRA, 2011, p. 122). The Jesuit priest João Daniel repeated the claim that before the arrival of Europeans, "there was such a crowd and abundance [of turtles], that sometimes the boats could not navigate". He complained how turtle exploration had a local impact on turtle populations. He reported that "after the turtles faced these enemies [the settlers], they caused them such damage that in many places, where formerly a crowd of turtles hampered the navigation, today is not possible to harvest a single one" (DANIEL, 1976, p. 96).

In his Memórias, Ferreira commented on how the wasteful hunting practices and eggs harvest could have a long-term impact on turtle populations:

This amphibian, so useful for the State, did not receive the required care or measures to prevent the abuses that are practiced. It takes time for a turtle to reach its full size. Every year, numerous turtles are wasted at the natives' discretion; all clutches are unburied, smashed and most parts of little turtles are unnecessarily eaten, which together account for its scarcity over time (FERREIRA, 1903, p. 184).

These historical narratives reveal no sense of remorse but reflect more utilitarian purposes. Ferreira's recommendation for the need to establish some form of control over the turtle exploitation also highlight that settlers' livelihood depended on these animals. At the same time, some historians have argued that Ferreira's recommendations can be read as a political consciousness concerning environmental protection ${ }^{17}$.

The historical accounts' descriptions of turtle abundance are so different from today's conditions that at first they seem scarcely believable. Even though there are few comprehensive studies on the $P$. expansa population ecology, data from the Amazonian Chelonian Protection and Management Project address this fact. The project was created in 1979, by the now extinct Brazilian Institute for Forestry Development (IBDF). Its main objective was to identify and protect the most important giant South American river turtle's nesting beaches, preventing the capture of the adult females and the taking of eggs. Other actions included the extraction of nests on floodplains, as well as the hatchlings to prevent predatory actions. Between 1980 and 2004, around 120 P. expansa nesting beaches were protected,

${ }^{17}$ See, for exemple, PÁDUA, 2002, p. 86-89. 
in the Brazilian States of Acre, Amapá, Amazonas, Goiás, Mato Grosso, Pará, Rondônia, and Tocantins. In 1997, around 30,000 turtles nested in the protected beaches, the highest number registered - and if we consider the lack of financial and human resources, the total number must have been a little higher (CANTARELLI; MALVASIO; VERDADE, 2014, p. 124-28). However, this number is smaller than the total number of turtles which were captured by the royal fisheries in the 1780 s.

Turtle hunting and egg harvesting had a local impact on giant South American river turtle populations. In 1977, the geographer Nigel Smith spent months in a field study in Itacoatiara and the Saracá lake surroundings (currently called Canaçari lake), one of the former main female and egg collecting points for Portuguese settlers. He noticed that fisherman hardly found $P$. expansa, focusing their effortsinstead on catching two other species: the yellow-spotted Amazon river turtle (P. unifilis) and the six-tubercled Amazon river turtle (P. sextuberculata) (SMITH, 1979, p. 165-176; SMITH, 1981, p. 2-3, 96). The same happened in the beaches of Madeira river, where the giant South American stocks crashed (KELLER et al., 2016, p. 8). In short, after three centuries of exploitation, turtles, especially $P$. expansa, decreased dramatically and were depleted in many nesting grounds.

\section{Conclusion}

Was eighteenth-century turtle hunting large enough to have an impact on $P$. expansa populations? Most historians and biologists have paid scant attention to turtle hunting and egg harvesting prior to the nineteenth-century, but colonial turtle exploitation cannot be underestimated. The giant South American river turtle was an abundant resource, free for the taking, and could be easily exploited. Many settlers viewed turtles as an endless resource. Portuguese settlers received large benefits from the harvest of these animals and their eggs. Turtles provided an extraordinary resource of fresh meat all year round, as well as oil suitable for cooking and lighting. On the other hand, Portuguese exploitation of giant South American river turtle had a doubly damaging effect. Massive captures of several thousand nesting females reduced the number of reproductive turtles, while oil production decreased recruitment of new individuals into the population. From historical reports on Amazon, Smith estimated that around 200,000,000 eggs were harvested between 1700 and 1903 (SMITH, 1979, p. 168), but eighteenth-century evidence suggests that the number of eggs collected was significantly higher.

The giant South American river turtle did not become extinct. Turtle hunting and egg harvesting continued throughout the nineteenth and into on twentieth century, probably at a rate as high or higher than before. This intense exploitation of female turtles and eggs resulted in severe long-term impacts. P. expansa populations declined drastically and, in 
some areas, as the Madeira River and Canaçari Lake, where the species was easily and abundantly collected in the eighteenth-century, these turtles were virtually eliminated. Great longevity, delayed sexual maturity, and a high juvenile mortality of giant South American river turtles associated with uncontrolled exploitation, affected population stability ${ }^{18}$. Today, the International Union for the Conservation of Nature (IUCN) considers the giant South American river turtle a species of "lower risk/conservation dependent" for extinction ${ }^{19}$. However, it would be interesting to analyze the current patterns as a historical phenomenon, considering the distribution and abundance of these populations over the time.

Although epidemic diseases spread by the Portuguese reduced the population of Indian societies, the assimilation of Indian knowledge was important for the settlers. Indian intimate knowledge of animals, plants and environments permitted the Europeans to exploit turtles and other natural resources of the Amazon rainforest. At the same time, Indian participation in turtle hunting and egg oil production was essential. Indians supplied the human energy needed to collect turtles and eggs for the oil industry, and Portuguese settlers organized and managed Indians for these activities.

Finally, Portuguese turtle exploitation in the Amazon rainforest can be understood in a broader context of European maritime contact with the New World. European settlements in the New World had an impact on wildlife and ecosystems. That impact came in several forms, such as habitat destruction, search for commodities, and hunting. However, the environmental dimensions of Amazonian colonial history have been scarcely explored.

\section{Fontes impressas}

ACUÑA, Cristóbal de. Nuevo descubrimiento del gran rio de las Amazonas. Madrid: Imprenta del Reyno, 1641.

ALHO, Cypriano Pereira. A Muhraida, ou a conversão, e reconciliação do gentiomuhra. Poema heroico em seis cantos, composto por H. J. Wilkens. Dado á luz, e offerecido ao Ex.mo e Rev. mo Senhor D. Antonio José d'Oliveira, bispo d'Eucarpia, suffraganeo coadjutor, e provisor do Arcebispado de d'Evora, do Conselho de S. Magestade, etc. etc. etc, pelo seu capellão o P. Cypriano Pereira Alho, presbytero eborense. Lisboa: Impressão Regia, 1819.

BATES, Henry Walter. The naturalist on the river Amazons: a record of adventures, habits od animals, sketches of brazilian and indian life, and aspects of nature under the equator, during eleven years of travel. Londres: John Murray, 1864.

\footnotetext{
${ }^{18}$ See also SCHNEIDER et al., 2011.

${ }^{19}$ TORTOISE \& FRESHWATER TURTLE SPECIALIST GROUP. Podocnemis expansa (errata version published in 2016). The IUCN Red List of Threatened Species 1996: e.T17822A97397263. http://dx.doi. org/10.2305/IUCN.UK.1996.RLTS.T17822A7500662.en. Downloaded on 26 January 2019.
} 
BRUNELLI, Giovanni Angelo. De flumine Amazonum. In: PAPAVERO, Nelson; CHIQUIERI, Abner; OVERAL, William; SANJAD, Nelson; MUGNAI, Riccardo. Os escritos de Giovanni Angelo Brunelli (1722-1804), astrônomo da comissão demarcadora de limites, sobre a Amazônia brasileira. Belém: Fórum Landi, 2011, p. 122-163.

CARVAJAL, Frei Gaspar de. Relatório do novo descobrimento do famoso Rio Grande descoberto pelo Capitão Francisco de Orellana. São Paulo: Scritta, 1992.

CONDAMINE, Charles-Marie de la. Relation abrégée d'un voyage fait dans l'interieur de l'Amérique Méridionale. Depuis la Côte de la mer du Sud, jusqu'aux côtes du Brésil \& de la Guiane, e en descendant la riviere des Amazones. Paris: Veuve Pissot, 1745.

DANIEL, João. Tesouro descoberto no rio Amazonas. v. 1. Rio de Janeiro: Biblioteca Nacional, 1976.

FERREIRA, Alexandre Rodrigues. Memória sobre a Yurara-reté: as tartarugas, que foram preparadas e remettidas nos caixôes, n. 1 até n. 7 da primeira remessa. In: Archivos do Museu nacional do Rio de Janeiro, v. 12, p. 181-186, 1903.

FERREIRA, Alexandre Rodrigues. Memória sobre as tartarugas. In: FERREIRA, Alexandre Rodrigues. Viagem filosófica pelas capitanias do Grão-Pará, Rio Negro, Mato Grosso e Cuiabá: memórias zoologia e botânica. Rio de Janeiro: Conselho Federal de Cultura, 1972, p. 25-31. FERREIRA, Alexandre Rodrigues. Memória sobre as variedades de tartarugas que há no Estado do Grão-Pará e do uso que lhe dão. In: FERREIRA, Alexandre Rodrigues. Viagem filosófica pelas capitanias do Grão-Pará, Rio Negro, Mato Grosso e Cuiabá: memórias zoologia e botânica. Rio de Janeiro: Conselho Federal de Cultura, 1972, p. 33-35.

FERREIRA, Alexandre Rodrigues. Viagem filosófica ao Rio Negro. Belém: Círculo do Livro; Museu Emílio Goeldi, 1983.

FONSECA, José Gonsalves. Navegação feita da cidade do Gram Pará até à bocca do Rio da Madeira pela escolta que por este rio subio às Minas do Mato Grosso, por ordem mui recommendada de Sua Magestade Fidelissima no anno de 1749, escripta por Jose Gonsalves da Fonseca no mesmo anno. Colleç̧ão de noticias para a historia e geografia das naçōes ultramarinas, que vivem nos dominios portuguezes, ou the sấo vizinhas, v. 4, n. 1, 1826.

LANDI, Antonio Giuseppe. O códice: descrizione di varie piante, frutti, animali, passeri, pesci, biscie, rasine, e altre simili cose che si ritrovano in questa Cappitania del Gran Parà [ca. 1772]. In: PAPAVERO, Nelson; TEIXEIRA, Dante Martins; CAVALCANTE, Paulo. B.; HIGUCHI, Horácio. Landi: fauna e flora da Amazônia brasileira. Belém: Museu Paraense Emílio Goeldi; Ministério da Ciência e Tecnologia, 2002.

QUEIROZ, João de São Joseph. Viagem e visita do sertão em o bispado do Gram-Pará em 1762 e 1763. Escripta pelo bispo D. Fr. João de S. José, monge benedictino. In: RIHGB, n. 9, p. 43-107, 179-227, 328-375, 476-527; 1869. 
SAMPAIO, Francisco Xavier Ribeiro de. Diario da viagem que em visita, e correição das povoaçóes da capitania de S. Joze do Rio Negro fez o Ouvidor, e Intendente geral da mesma Francisco Xavier Ribeiro de Sampaio no anno de 1774 e 1775; exornado com algumas noticias geograficas, e hydrograficas da dita capitania, com outras concernentes á historia civil,politica, e natural della, aos uzos, e costumes, e diversidade de naçôes de indios seus habitadores, e á sua população, agricultura, e commercio. Lisboa: Typografia da Academia, 1825.

\section{Fontes manuscritas}

Ofício do [governador do Estado - Pará e Maranhão], Francisco [Xavier de Mendonça Furtado] ao [secretário de Estado dos Negócios do Reino], Sebastiáo José de Carvalho e Melo sobre provisão de mantimentos, Arraial de Mariuá, 13 jul. 1755. Arquivo Histórico Ultramarino_CU_020, Caixa 1, Documento 34.

Ofício do [encarregado das demarcações do Rio Negro e capitão-general], João Pereira Caldas, ao [secretário de estado da Marinha e Ultramar], Martinho de Melo e Castro, sobre a prestação de contas dos gastos da expedição no ano de 1780, Vila de Barcelos, 22 jul. 1781. Arquivo Histórico Ultramarino_CU_020, Caixa 4, Documento 221.

Ofício do [encarregado das demarcaçóes do Rio Negro e capitáo-general], João Pereira Caldas, a [secretário de estado da Marinha e Ultramar], Martinho de Melo e Castro, a enviar as relaçôes das despesas feitas em 1781 pela Junta da Real Fazenda do Pará com a expedição das demarcaçôes do Rio Negro, Vila de Barcelos, 5 fev. 1783. Arquivo Histórico Ultramarino_CU_020, Caixa 6, Documento 264.

Ofício do [encarregado das demarcaçóes do Rio Negro e capitáo-general], João Pereira Caldas, ao [secretário de estado da Marinha e Ultramar], Martinho de Melo e Castro, sobre as despesas da Repartição das Demarcaçôes no ano de 1782, Vila de Barcelos, 20 out. 1783. Arquivo Histórico Ultramarino_CU_020, Caixa 7, Documento 297.

Ofício do [encarregado das demarcaçôes do Rio Negro e capitáo-general], João Pereira Caldas, ao [secretário de estado da Marinha e Ultramar], Martinho de Melo e Castro, a enviar as contas da Repartição das Demarcaçóes, relativas ao ano de 1783, Vila de Barcelos, 20 fev. 1785. Arquivo Histórico Ultramarino_CU_020, Caixa 9, Documento 371.

Ofício do [capitão-general], João Pereira Caldas, ao [secretário de Estado da Marinha e Ultramar], Martinho de Melo e Castro, sobre as despesas relativas ao ano de 1786, feitas pela Repartição das Demarcações de Limites, a bordo da canoa Nossa Senhora do Pilar, 15 jun. 1789. Arquivo Histórico Ultramarino_CU_020, Caixa 15, Documento 564.

Ofício do [capitão-general], João Pereira Caldas, ao [secretário de estado da Marinha e Ultramar], Martinho de Melo e Castro, sobre as despesas relativas ao ano de 1787, feitas 
pela Repartição das Demarcações de Limites, a bordo da canoa Nossa Senhora do Pilar, 15 jun. 1789. Arquivo Histórico Ultramarino_CU_020, Caixa 15, Documento 566.

\section{Referências}

ANDERSON, Robin. Colonization as Exploitation in the Amazon Rain Forest, 1758-1911. Gainesville: University Press of Florida, 1999.

ANDERSON, Virginia DeJohn. Creatures of Empire: how domestic animals transformed early America. New York: Oxford University Press, 2006.

ASÚA, Miguel de; FRENCH, Roger. A New World of Animals: Early Modern Europeans on the creatures of Iberian America. Aldershot: Ashgate, 2005

BEST, Robin. The Aquatic Mammals and Reptiles of the Amazon. In: SIOLI, Harald (org.). The Amazon: limnology and landscape ecology of a mighty tropical river and its basin. Dordrecht: Dr. W. Junk Publishers, 1984.

CANTARELLI, Vitor; MALVASIO, Adriana; VERDADE, Luciano. Brazil's Podocnemis expansa Conservation Program: retrospective and future directions. Chelonian Conservation and Biology, v. 13, n. 1, p. 124-28, 2014.

CHAMBOULEYRON, Rafael. Plantações, sesmarias e vilas. Uma reflexão sobre a ocupação da Amazônia seiscentista. Nuevo Mundo Mundos Nuevos, v. 6, p. 1-10, 2006.

CHAMBOUlEYRON, Rafael. Cacao, Bark-Clove and Agriculture in the Portuguese Amazon Region in the Seventeenth and Early Eighteenth-Century. Luso-Brazilian Review, v. 51, p. 1-35, 2014.

CLEARY, David. Towards an Environmental History of the Amazon: from prehistory to the nineteenth-century. Latin American Research Review, v. 36, p. 64-96, n. 2, 2001, p. 84 CLEMENT, Charles, DENEVAN, William; HECKENBERGER, Michael; JUNQUEIRA, André; NEVES, Eduardo; TEIXEIRA, Wenceslau; WOODS, William. The Domestication of Amazonia Before European Conquest. Proceedings of the Royal Society B, v. 282, n. 1812, p. 1-9, 2015.

COSTA, Kelerson Semerene. Natureza, colonização e utopia na obra de João Daniel. História, Ciências, Saúde - Manguinhos, v. 14, supl., 2007, p. 95-112.

COSTA, Kelerson Semerene. Templos de Tânatos, templos de Eros: a exploração da tartaruga nas praias amazônicas. In: FRANCO, José de A.; DRUMMOND, José A.; SILVA, Sandro D.; TAVARES, Giovana G. (orgs.). História ambiental: fronteiras, recursos naturais e conservação da natureza. Rio de Janeiro: Garamond, 2012.

CRAMPTON, William; CASTELLO, Leandro; VIANA, João Paulo. Fisheries in the 
Amazon Várzea. In: SILVIUS, Kirsten; BODMER, Richard; FRAGOSO, José M. V. (orgs.). People in Nature: wildlife conservation in South and Central America. New York: Columbia University Press, 2004, p. 76-98.

CRAWFORD, Sharika. Disputas marítimas en el Caribe colombiano: la pesca de tortugas en el archipiélago de San Andrés y Providencia, 1910-1930. Historia Crítica, v. 66, p. 67-85, 2017.

DENEVAN, William. A Bluff Model of Riverine Settlement in Prehistoric Amazonia. Annals of the Association of American Geographers, v. 86, n. 4, p. 654-681, 1996.

DOMINGUES, Ângela. Viagens de exploração geográfica na Amazónia em finais do século XVIII: política, ciência e aventura. Lisboa: Centro de Estudos de História do Atlântico, 1991.

DOMNING, Daryl. Commercial Exploitation of Manatees Trichechus in Brazil c. 17851973. Biological Conservation, v. 22, p. 101-126, 1982.

FACHÍN-TERÁN, Augusto; VOGT, Richard; THORBJARNARSON, John. Patterns of use and hunting of turtles in the Mamirauá Sustainable Development Reserve, Amazonas, Brazil. In: SILVIUS, Kirsten; BODMER, Richard; FRAGOSO, José M. V. (orgs.). People in Nature: wildlife conservation in South and Central America. New York: Columbia University Press, 2004, p. 362-377.

FERRARA, Camila; VOGT, Richard; SOUSA-LIMA, Renata; TARDIO, Bruno; BERNARDES, Virginia. Sound Communication and Social Behavior in an Amazonian River Turtle (Podocnemis expansa). Herpetologica, v. 70, n. 2, p. 149-56, 2014.

FEW, Martha; TORTORICI, Zeb (orgs.). Centering Animals in Latin American History. Durham: Duke University Press, 2013.

FIORI, Marlon; SANTOS, Christian F. M. dos. A carne, a gordura e os ovos: colonização, caça e pesca na Amazônia. Porto Alegre: EDIPUCRS, 2015.

GILMORE, Raymond. Fauna e etnozoologia da América do Sul tropical. In: RIBEIRO, Berta (org.). Suma etnológica brasileira. v. 1. Petrópolis: Vozes, 1987, p. 189-233.

GOELDI, Emílio. Alexandre Rodrigues Ferreira. Brasília: Editora UNB, 1982.

GOUDING, Michael. História natural dos rios amazônicos. Brasília: Sociedade Civil Mamirauá; CNPq; Rainforest Alliance, 1997.

HENNESSY, Elizabeth. The Molecular Turn in Conservation: genetics, Pristine Nature, and the rediscovery of an Extinct Species of Galápagos Tortoise. Annals of the Association of American Geographers, v. 105, n. 1, p. 87-104, 2014.

HOLANDA, Sérgio Buarque de. Monçōes. São Paulo: Brasiliense, 2000.

IRION, Georg; JUNK, Wolfgang; MELLO, José. The Large Central Amazonian River Floodplains Near Manaus: geological, climatological, hydrological and geomorphological 
aspects. In: JUNK, W. (org.). The Central Amazon Floodplain: ecology of a pulsing system. Berlim: Springer, 1997.

KELLER, Claudia; VILLAMARÍN, Francisco; BERNHARD, Rafael; SILVA, Daniely F. da. Checklist of Chelonians from the Upper Madeira River and the Lower Madeira-Purus Interfluvium (Brazilian Amazon), Including a Range Expansion for Podocnemis sextuberculata Cornalia, 1849. Check List, v. 12, n. 4, p. 1-32, 2016.

KLEMENS, Michael; THORBJARNARSON, John. Reptiles as a Food Resource, Biodiversity and Conservation, v. 4, n. 3, p. 281-98, 1995.

MACHADO, Diego Ramon Silva. No rastro dos ovos: uma história da exploraçáo e uso da tartaruga da Amazônia (Podocnemis expansa Schweigger, 1812), 1727-1882. Tese (Doutorado em História das Ciências) - Programa de Pós-Graduação em História das Ciências, Casa de Oswaldo Cruz-Fiocruz, Rio de Janeiro, 2016.

MEIRA FILHO, Augusto. Landi, esse desconhecido. Brasília: Conselho Federal de Cultura e Departamento de Assuntos Culturais, 1976.

MITTERMEIER, Russel. A Turtle in Every Pot: a valuable South American resource going to wast. Animal Kingdom, v. 78, n. 2, p. 9-14, 1975.

MORAES, Eulália; SANTOS, Christian F. M. dos; CAMPOS, Rafael D. da S. Filosofia natural lusa: a Viagem Philosophica e a política iluminista na América portuguesa setecentista. Confluenze, v. 4, n. 1, p. 75-91, 2011.

PÁDUA, José Augusto. Um sopro de destruição: pensamento político e crítica ambiental no Brasil escravista (1786-1888). Rio de Janeiro: Jorge Zahar Ed., 2002.

PAPAVERO, Nelson; TEIXEIRA, Dante Martins. A "Muhraida", poema heróico de Henrique João Wilkens (1785) e seus impressionantes dados sobre o morticínio da tartaruga amazônica. Contribuiçôes Avulsas sobre a História Natural do Brasil. Série História da História Natural, Seropédica, v. 22, p. 1-5, 2000.

PAPAVERO, Nelson; SANJAD, Nelson; CHIQUIERI, Abner; OVERAL, William; MUGNAI, Ricardo. Os escritos de Giovanni Angelo Brunelli, astrônomo da Comissão Demarcadora de Limites portuguesa (1753-1761), sobre a Amazônia brasileira, Boletim do Museu Paraense Emílio Goeldi - Ciências Humanas, v. 5, n. 2, 493-533, 2010.

PAPAVERO, Nelson; TEIXEIRA, Dante Martins. Os animais do Estado do Grão-Pará segundo um manuscrito do jesuíta Antônio Moreira (ca. 1750). Arquivos de Zoologia, v. 42, n. 2, p. 83-131, 2011.

PAPAVERO, Nelson; COURI, Marcia; TEIXEIRA, Dante Martins; CHIQUIERI, Abner. As notas do padre Anselm Eckart, S. J. sobre alguns animais do Estado do Grão-Pará e Maranhão (1785). Boletim do Museu Paraense Emílio Goeldi - Ciências Humanas, v. 6, n. 3, p. 593-609, 2011. 
PATACA, Ermelinda Moutinho. Coletar, preparar, remeter, transportar práticas de história natural nas viagens filosóficas portuguesas (1777-1808). Revista Brasileira de História da Ciência, v. 4, n. 2, p. 125-138, 2011.

RAMINELLI, Ronald. Ciência e colonização: a viagem filosófica de Alexandre Rodrigues Ferreira. Revista Tempo, v. 6, p. 157-182, 1998.

RAMINELLI, Ronald. Viagens ultramarinas: monarcas, vassalos e governo a distância. São Paulo: Alameda, 2008.

RAYMUNDO, Letícia de Oliveira. O Estado do Grão-Pará e Maranhão na nova ordem política pombalina: a Companhia Geral do Grão-Pará e Maranhão e o Diretório dos Índios (1755-1757). Almanack braziliense, v. 3, p. 124-34, 2006.

ROLLER, Heather Flynn. Expediçôes coloniais de coleta e a busca por oportunidades no sertão amazônico, c. 1750-1800. Revista de História, n. 168, p. 201-243, 2013.

SAFIER, Neil. 'Every day that I travel ... is a page that I turn': reading and observing in eighteenth-century Amazonia. Huntington Library Quarterly, v. 70, n. 1, p. 103-128, 2007. SCHNEIDER, Larissa; FERRARA, Camila, VOGT, Richard C.; BURGER, Joanna. History of Turtle Exploitation and Management Techniques to Conserve Turtles in the Rio Negro Basin of the Brazilian Amazon. Chelonian Conservation and Biology, v. 10, n. 1, p. 149-57, 2011.

SMITH, Nigel. Destructive Exploitation of the South American River Turtle. Yearbook of the Association of Pacific Coast Geographers, n. 36, p. 85-102, 1974.

SMITH, Nigel. Aquatic Turtles of Amazonia: an endangered resource. Biological Conservation, n. 3, p. 165-76, 1979.

SMITH, Nigel. Man, fishes, and the Amazon. Nova York: Columbia University Press, 1981. TORTOISE \& FRESHWATER TURTLE SPECIALIST GROUP. Podocnemis expansa (errata version published in 2016). The IUCN Red List of Threatened Species 1996: e.T17822A97397263. http://dx.doi.org/10.2305/IUCN.UK.1996.RLTS. T17822A7500662.en. Downloaded on 26 January 2019.

TREECE, David. Exiles, Allies, Rebels: Brazil's indianist movement, indigenist politics, and the imperial nation-state. Westport: Greenwood Press, 2000.

VERÍSSIMO, José. A pesca na Amazônia. Belém: Universidade Federal do Pará, 1970.

VOGT, Richard; MOREIRA, Gláucia; DUARTE, Ana C. de O. Biodiversidade de répteis do bioma floresta amazônica e ações prioritárias para sua conservação. In: CAPOBIANCO, João; VERÍSSIMO, Adalberto; MOREIRA, Adriana; SAWYER, Iza dos S.; PINTO, Luiz P. (orgs.). Biodiversidade da Amazônia brasileira: avaliação e açôes prioritárias para a conservação, uso sustentável e repartição de benefícios. São Paulo: Estação Liberdade, 2001, p. 89-96. 
VOGT, Richard. Tartaruga fluvial gigante sul-americana (Podocnemis expansa Schweigger, 1812) (Pelomedusidae). In: CINTRA, Renato (org.). História natural, ecologia e conservação de algumas espécies de plantas e animais da Amazônia. Manaus: EDUA; INPA; FAPEAM, 2004.

VOGT, Richard. Tartarugas da Amazônia. Lima: Gráfica Biblos, 2008. 